\title{
The Utilization of Wonorejo Mangrove Ecotourism Area as a Contextual Learning Source
}

\author{
Sri Murtini \\ Geography Education \\ Universitas Negeri Surabaya \\ Surabaya, Indonesia \\ srimurtini@unesa.ac.id
}

\author{
Sumarmi, I Komang Astina, Dwiyono Hari Utomo \\ Geography Education \\ Universitas Negeri Malang \\ Malang, Indonesia
}

\begin{abstract}
Wonorejo ecotourism area has not yet been utilized as a learning source. Regarding to this fact, this study was intended at investigating the suitability of Wonorejo ecotourism area as a learning source, and the effectiveness of Wonorejo ecotourism area as a learning source. This study was conducted under the research and development procedure proposed by Borg \&Gall. The subjects of this study included 32 university students majoring Geography who were divided into $A$ class as the experimental class, and B class for the control class. This study employed a quasi-experimental design of which data were obtained from interviews and tests. Validations were done by an expert of learning materials to see the suitability of the area for education and T-test was administered to see its effectiveness. This research showed that the Wonorejo ecotourism area is highly effective to be used as a contextual learning source for students with $90.0 \%$ average score. As a learning source, Wonorejo ecotourism area is also effective to improve the learning achievement of the undergraduate students majoring Geography of 2014 academic year in the Geography of Tourism subject.
\end{abstract}

Keywords—suitability, effectiveness, mangrove ecotourism area

\section{INTRODUCTION}

Learning source is a part of learning process that holds various and vital functions. Learning source refers to any learning materials which are systematically arranged. Learning source is used in the learning activity and it reflects the overall competences that should be achieved by students. For instance, text books, modules, handout, work sheet, realia, interactive audio, media, and so on. Hermawan, et al [1] mentioned that learning source has several functions as, i.e. a guide to direct all of the teaching and learning activity and the materials to match the competences, a guide for teachers to create teaching and learning activities that go in line with the target competences, and a tool to evaluate students' achievement.

Developing a learning material is also a crucial component in teaching and learning activity. Contextual learning refers to a teaching method that utilizes materials beyond a text book, in which materials are developed from students' real life context including physical, social, economic, cultural and psychological life [2]. More importantly, self-made learning materials make the learning process in the university easier [3].
Contextual learning method is efficient because it directs students to find the correlation between the materials they are learning and their real life, it drives students to implement what they have learned into their real life, it emphasizes on how students construct their own understanding of the materials. Therefore, contextual teaching and learning is a good alternative to be implemented in teaching and learning activities [4].

Hosnan [2], [5], [6] have confirmed that contextual teaching and learning improve students' learning achievement. Contextual teaching and learning help students to find the meaning of a concept by relating the materials with their real life, which finally improves their academic competences [6]. Students' academic achievement is the target of the teaching and learning activities as stated in the National Framework Qualification of Indonesia.

A study conducted by [7] to students of the $1^{\text {st }}$ semester majoring Biology Teaching, Faculty of Education, IKIP Negeri Singaraja, shows a result that contextual teaching and learning strategy has a positive effect on students' learning achievement. Maryam, et al [8] also conducted a similar study to students of the $1^{\text {st }}$ semester majoring physical education in IKIP Negeri Singaraja which shows an improvement of students' achievement after being taught using contextual teaching and learning technique. Regarding to those empirical data, it can be concluded that contextual teaching and learning improve students' learning achievement.

Contextual teaching and learning relate the materials to students' real life experience at home, at school or in the society in order to let them find the meaning of learning for their life [9]-[12]. The utilization of Wonorejo mangrove ecotourism area is expected to give contextual learning experience that helps students to connect the learning materials with the students' real life situations and drives them to construct their own understanding on the relationship between what they learn with their real lives.

This definition of contextual learning goes in line with the description of the qualification of each level in the National Qualification Framework of Indonesia which comprehensively focuses on the whole learning experience in every level to enhance the quality and the productivity of human resource. This target is also in accordance with the 
expected learning achievement as stated in the Standards of the Graduates which include three elements of attitude, knowledge and skills. Skills are classified into general skills and special skills which can be adjusted in certain ways for university graduates

As the learning source for the subject of Geography of Tourism, particular materials on ecotourism were merely presented as knowledge without emphasizing the correlation between the materials and students' real lives, making the students tend to memorize the concept without deeper comprehension. Based on the result of the questionnaires distributed to the students, 26 students $(81 \%)$ considered the learning materials dull and unattractive. Hence, the materials need to be developed to let the students understand them better.

In a survey, students pointed out some lacks of the materials including the materials still cannot help them to relate what they learn and the real life, the objectives of the lesson have not been explicitly stated and they had no idea about the goals of the ecotourism materials they learned, and the materials only provide sets of information in which concepts were presented as knowledge without any guidance for students to analyze and understand the materials to draw comprehensive conclusions.

Lecturers also have not yet utilized the Wonorejo ecotourism area as a learning source. Meanwhile, the target competences of the ecotourism subject support on-field contextual learning. Wonorejo ecotourism area can be utilized as a source for students to learn geography especially in the subject of geography for tourism, particularly the ecotourism chapter. Wonorejo ecotourism area provides various facilities that can be used for educational purposes such as environmental orientation, laboratory, research center, field-study, and so on. This area is also located in a relatively short distance which makes it a good alternative to be used as a learning source.

Regarding such background, a study to see the suitability and the effectiveness of Wonorejo mangrove ecotourism area as a contextual learning source was necessary to conduct.

\section{METHOD}

This study was administered by research and development method. The subjects of this study included 32 students majoring geographical science teaching class of 2014 from offering $\mathrm{A}$ as the experimental group and 30 students from offering B as the control group. This study was conducted in the geography teaching program of FISH Unesa. Likert scale was used in this study to measure the suitability of the materials. The Likert scale categorized the material suitability into 5 categories, namely $1=$ highly unsuitable, $2=$ unsuitable, $4=$ suitable, and $5=$ highly suitable. The validation form was used by the expert of materials to assess the materials. Meanwhile, the effectiveness of the materials was measured by comparing the scores obtained by the experimental group with the scores of the control group using an independent sample ttest. The test showed the score gap between the two groups. Paired sample t-test was also administered to see the influence of the utilization of Wonorejo mangrove ecotourism area as a learning source on the students' learning achievement.

\section{RESULTS AND DISCUSSIONS}

\section{A. Suitability of the Materials}

The seven components of the learning materials obtained an average value of $90.6 \%$. Based on the Likert scale categorization, $90.6 \%$ is highly suitable (81-100\%). Arikunto [13] mentioned that even though the materials have been considered as highly suitable, revisions are still necessary to make. Some aspects needed revisions including the basic competence, course description, objectives of the study, materials on sustainable tourism, development of the sustainable tourism, development strategies, effects of the development and questions.

The basic competence of the ecotourism chapter was not explicitly stated yet it was presented in the point of describing the potential factors to develop a tourism spot and development model of tourism. Therefore, in this point, a revision was necessary to put the ecotourism materials in the special point of ecotourism. The revision improved the score from 3 (suitable) to 4 (highly suitable).

The geographical competences for tourism course include group work, correct and precise implementation of various interactive analysis models related to tourism using environmental approach that matches the real condition in the field. This statement contains a large scope of interpretations in which ecotourism is seen as a part of sustainable tourism which is supposed to be presented as a focus of the discussion.

The first target competence, as stated in the course outline, mentions that students should be able to utilize various learning source and technology-based learning media to help them understand the course better. The geographical tourism materials should not only focus on the use of advanced technology, but also should be presented using an appropriate learning method. Contextual teaching and learning is a good alternative to help students relate the materials to their real live and it also drives the students to construct their own understanding on the correlation between the materials and their daily lives [14]. In Table 1 presents the results of the assessment of feasibility based on 17 aspects.

\section{B. Effectiveness of the Materials}

A pre-test and a post-test were administered to the Class A as the experimental group and to the Class B as the control group. Statistical hypothesis of this study was Ho where the data were normally distributed and $\mathrm{H} 1$ where the data were not normally distributed. Ho is rejected if $p<\alpha$ at $5 \%$ level of significance.

One of the conditions of the parametrical statistics is the normality test. To measure the normality of the data, researchers employed Kosmogorov Smirnov 1 sample statistical test. The result of the test was analyzed using an SPSS program which shows that the Class A obtained a $p$ value of 0.974 . Evaluation of the Suitability of Wonorejo Mangrove Ecotourism Area as a Learning Source. 


\begin{tabular}{|c|c|c|c|c|c|c|}
\hline \multirow[t]{2}{*}{ No. } & \multirow[t]{2}{*}{ Aspects } & \multicolumn{4}{|c|}{ Score } & \multirow[t]{2}{*}{$\%$} \\
\hline & & 1 & 2 & 4 & 5 & \\
\hline 1. & Suitability to the basic competences & & & 4 & & 80 \\
\hline 2 & Suitability to the course description & & & 4 & & 80 \\
\hline 3. & Suitability to the learning objectives & & & 4 & & 80 \\
\hline 4. & Suitability to the expected achievement & & & & 5 & 100 \\
\hline 5. & Suitability to the indicators & & & & 5 & 100 \\
\hline 6. & Materials of the sustainable tourism & & & 4 & & 80 \\
\hline 7. & Materials of the tourism potency & & & & 5 & 100 \\
\hline 8. & Materials of the facilities & & & & 5 & 100 \\
\hline 9. & $\begin{array}{l}\text { Materials of the development of } \\
\text { sustainable tourism }\end{array}$ & & & 4 & & 80 \\
\hline 10. & Materials of the development strategies & & & 4 & & 80 \\
\hline $11 .$. & Materials of the environmental supports & & & & 5 & 100 \\
\hline 12. & Materials of the effect of the development & & & 4 & & 80 \\
\hline 13. & Understandable questions & & & 4 & & 80 \\
\hline 14. & Evaluation part & & & & 5 & 100 \\
\hline 15. & Availability of the answer key & & & & 5 & 100 \\
\hline 16. & Availability of the glossary list & & & & 5 & 100 \\
\hline 17. & Availability of the references & & & & 5 & 100 \\
\hline \multicolumn{6}{|c|}{ Average score } & $\begin{array}{l}90.6 \\
\%\end{array}$ \\
\hline
\end{tabular}

${ }^{\text {a. }}$ Source: Primary Data, 2017

Since the $p>\alpha(0.05)$ so that the Ho is accepted, which implies that the scores of the pre-test of the Class A were normally distributed. Concurrently, the posttest results of the Class A obtained a p-value of 0.729 since the $p>0.05$ so that the Ho is accepted, which also implies that the posttest scores were normally distributed. In conclusion, the scores of the pretest and the posttest of Class A were normally distributed. Therefore, the parametric statistic test in the form of a t-paired test could be administered.

The data were tested using the t-paired test of SPSS program in which the statistical hypothesis stated that there is no significant difference between the scores of the pretest and posttest. Meanwhile, the H1 states that there is a significant difference between the score of the pretest and posttest. The Ho is rejected if $p<\alpha$. Based on the result of the data analysis, the $p$ value shows 0.000 significance level since the $p<\alpha$ so that the H1 is accepted. Therefore, it is implied that there is a significant difference between the value of the pretest and the posttest. This phenomenon is normal considering the experimental group was given better learning materials which eventually helped them to improve their achievement.

The data analysis of the pre-test score of the Class B was administered within the statistical hypothesis in Ho if the data are normally distributed, and $\mathrm{H} 1$ if the data are not normally distributed. The result of the analysis using SPSS program shows a $\mathrm{p}$ value at 0.862 since $\mathrm{p}<\alpha$, then the Ho is accepted, which means that the data are normally distributed. Meanwhile, the analysis of the scores from the post-test shows $p=0.623>$ $\alpha$. Since the $p$ value is greater than the level of significance, the Ho is accepted, which means that the data are normally distributed. Therefore, a parametric statistic test in the form of a t-paired test could be administered.

To see the learning achievement gap between Class A and $\mathrm{B}$, the t-paired independent sample test and homogeneity test were conducted. The homogeneity test was done using the Levene's statistical test. In testing the data homogeneity, the Ho refers to the homogeneous variants, and $\mathrm{H} 1$ refers to the heterogeneous variants. The Ho is rejected if the $p<\alpha$. The result of the pre-test score analysis shows $p=0.791$. Since $p>$ $\alpha$, the Ho is accepted, which implies that the data of the pre-test score are homogeneous. Meanwhile, the result of the posttest score analysis shows $\mathrm{p}=0.517$. Since $\mathrm{p}<\alpha$, Ho is accepted, which implies that the data variance of the post-test score are homogeneous.

T-paired independent test was used to see the gap between the Class A and B. This test was conducted to the results of both the pretest and posttest of the two classes. In this test, the Ho means there is no significant difference between the results of the pre-test obtained by Class A and B. Meanwhile, the H1 means that there is a significant difference between the result of the pretest obtained by Class A and B. The Ho is rejected if $p<\alpha$. The result of the test shows $p=0.404>\alpha$, which accepts the Ho. It can be concluded that there is no significant difference between the pretest scores Class A and B. Thus, both classes have an equal ability to receive the treatments.

To see the gap between the result of the posttest of the class $\mathrm{A}$ and $\mathrm{B}$, the researchers set the hypothesis in Ho when there is no difference between the posttest results of the posttest of class A and B. The Ho is rejected when $p<\alpha$. As seen from the result of the measurement in which $p$ is found to be $0.000<\alpha$, the $\mathrm{H} 1$ is accepted, which means that there is a significant difference between the posttest scores obtained by class A and B. This t-paired test which shows different values means that different treatments received by those classes make different results. As confirmed in research done by [15] contextual teaching and learning is effective to stimulate students' ability to solve problems and to grow students' scientific attitude.

Regarding the minimum passing score in the university in which the lowest score to pass a course is set at 55 (C), $78.1 \%$ of students from the class A passed the pre-test, while 7 students $(21.9 \%)$ failed the pretest. After this class received the treatment, 32 students $(100 \%)$ successfully passed the posttest. Hence, it can be implied that the use of ecotourism area as a learning source has improved students' learning achievement. Wulandari [16] also found that the use of contextual teaching and learning to teach students' the materials on the 15 classifications of 15 chemical elements is effective to be applied in the teaching of Inorganic Chemistry I course.

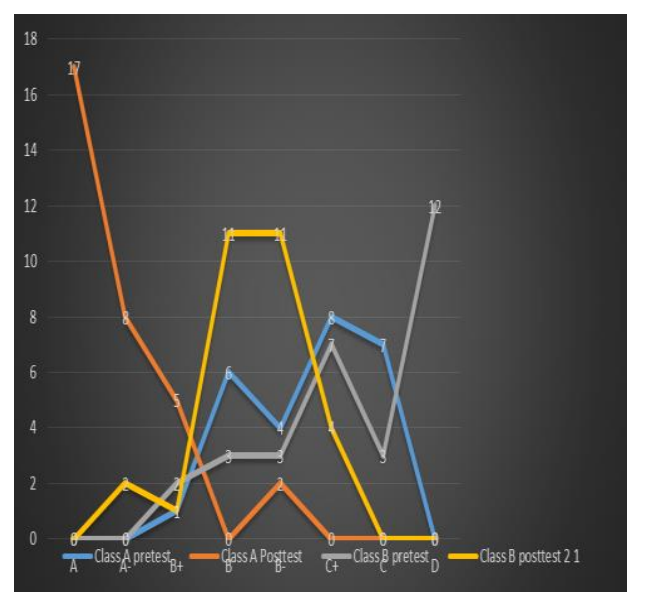

Fig. 1. Distribution of Pre-test and Post-test Score of Class A and Class B 
Notes:

$$
\begin{array}{ll}
\text { Score A }=85-100 & \text { Score } \mathrm{B}-=65-<70 \\
\text { Score A- }=80-<85 & \text { Score } \mathrm{C}+=60-<65 \\
\text { Score } \mathrm{B}+=75-<80 & \text { Score } \mathrm{C}=55-<60 \\
\text { Score B }=70-<75 & \text { Score } \mathrm{D}=<55
\end{array}
$$

After the data were analyzed, it can be seen that there were 12 students $(40 \%)$ from class B who did not pass the pretest and 18 other students $(60 \%)$ passed the test. Even though the results of the posttest from class A and B show that $100 \%$ students from both classes successfully passed the test, the score distribution is different. The following graph illustrates the score distribution of both classes.

From the result of the t-paired test, it can be concluded that there is a significant improvement on the learning achievement of class A and B. However, as the experimental group, Class A shows higher improvement than the class B (control group) without the treatment.

The score distribution of the post-test score obtained by class $\mathrm{A}$ shows that the lowest score is B- obtained by 2 students, B+ obtained by 5 students, A- obtained by 8 students and the most of the students (17 students) obtained an A. Whereas, the distribution of the posttest score of the class B shows the lowest score of $\mathrm{C}$ obtained by 1 student, B- obtained by 4 students, B obtained by 11 students, B+ obtained by 11 students, A- obtained by 1 student and only 2 students obtained an A.

It can be summarized that learning achievement of the class A as the experimental group is improved by the use of the contextual learning source. It has been proven that Wonorejo mangrove ecotourism can be utilized as a contextual learning source which effectively improves students' learning achievement. The use of the ecotourism area as a contextual learning source enhances the understanding of undergraduate students majoring Geography Teaching of the material of ecotourism presented in the Geography for Tourism course of 2014 academic year.

\section{CONCLUSIONS}

The Wonorejo mangrove ecotourism area is suitable as a contextual learning source. Contextual learning is a type of learning that utilizes the surrounding environment as a source of learning so that students can be more familiar with the environment while also taking care of it. The students' learning activities becomes more varied and their learning outcomes increase.

\section{REFERENCES}

[1] H. Hermawan, P. Permasih, and D. Dewi, "Pengembangan Bahan Ajar," 2012.

[2] K. Komalasari, Pembelajaran Kontekstual Konsep dan Aplikasi. Bandung: PT. Refika Aditama, 2014.

[3] I. Kurniasih and B. Sani, Panduan Membuat Bahan Ajar Buku Teks Pelajaran Sesuai dengan Kurikulum 2013. Surabaya: Kata Pena, 2014.

[4] S. Suyadi, Stategi Pembelajaran Pendidikan Karakter. Bandung: PT. Remaja RosdakaryA, 2015.

[5] M. Hosnan, Pendekatan Saintifik dan Kontestual Dalam Pembelajaran Abad 21: Kunci Sukses Implementasi Kurikulum 2013. Bogor: Ghalia Indonesia, 2014.

[6] B. Johnson, E, "Contextual Teaching and Learning: Menjadikan Kegiatan Belajar Mengajar Mengasyikan dan Bermakna," Setiawan, Ed. Bandung: Kaifa, 2014

[7] N. M. S. Mertasari, "Peningkatan Penguasaan Konsep dan Hasil Belajar Mahasiswa Jurusan Pendidikan Biologi Dalam Mata Kuliah Kalkulus I dengan Penerapan Strategi Pembelajaran Kontekstual melalui Pendekatan Pemecahan Masalah," IKIP Negeri Singaraja, 2005.

[8] S. Maryam and S. Suheimi, "Implementasi Pembelajaran Kontekstual Melalui Model Pembelajaran Kooperatif Berbantuan Buku Ajar Untuk Meningkatkan Aktivitas Dan Hasil Belajar Kimia Dasar Mahasiswa Jurusan Ilmu Keolahragaan,” J. Pendidik. dan Pengajaran, vol. 39, no. 2005, pp. 397-418, 2005.

[9] Z. Aqib, Model-Model Media dan Strategi Pembelajaran Kontekstual (Inovatif). Bandung: Yrama Widya, 2013.

[10] E. D. Baker, L. Hope, and K. Karandjeff, "Contextualized Teaching \& Learning: A Faculty Primer." Academic Senate for California Community Colleges, 2009.

[11] J. Bennett and J. Holman, Context-based approaches to the teaching of chemistry: What are they and what are their effects? Kluwer Academic Publishers, 2002.

[12] R. G. Berns and P. M. Erickson, "Contextual Teaching and Learning The Highlight Zone," http://nccte.org, 2001. [Online]. Available: http://nccte.org/publications/infosynthesis/highlightzone/highlight05/index.asp. [Accessed: 25-Feb-2016].

[13] A. Arikunto and S. Suharsimi, Dasar-dasar Evaluasi Pendidikan. Jakarta: Bumi Aksara, 2012.

[14] T. Trianto, Model-Model Pembelajaran Inovatif Berorientasi Konstruktifistik. Jakarta: Prestasi Pustaka, 2007.

[15] E. Suryawati, O. Kamisah, and T. S. M. Meerah, "The effectiveness of RANGKA contextual teaching and learning on students' problem solving skills and scientific attitude," Procedia-Social Behav. Sci., vol. 9, pp. 1717-1721, 2010.

[16] A. Wulandari, "Pengembangan Bahan Ajar Unsur Golongan 15 berbasis Kontekstual Untuk Mata Kuliah Kimia Anorganik,” 2016. 